\title{
EFFECTIVENESS OF MULTILEVEL HEALTH PROMOTION ON EXCLUSIVE BREASTFEEDING IN JEMBER, EAST JAVA
}

\author{
Nur Khamidah'), Yayi Suryo Prabandari²), Detty Siti Nurdiati3) \\ ${ }^{1)}$ Department of Public Health, Medicine Faculty, Universitas Wijaya Kusuma \\ 2)Postgraduate Program of Health Promotion and Behavior, \\ Faculty of Medicine, Universitas Gadjah Mada \\ 3)Department of Obstetrics and Gynecology, Sardjito General Hospital, \\ Universitas Gadjah Mada
}

\begin{abstract}
Background: The need for multilevel and comprehensive health promotion programmes has become widely accepted, as has the importance of community approaches. Multilevel-Multicomponent (ML-MC) interventions are interventions that work on more levels at the same time and that involves more intervention components that are synchronized across levels. As a result, they require extensive community engagement. This study aimed to examine the effectiveness of multilevel health promotion on enhancing exclusive breastfeeding practice among lactating women in Jember, East Java.

Subjects and Method: This was a mix method study (qualitative and quantitative) conducted in Jember, East Java. A sample of 245 lactating women was selected for this study, divided in 2 groups: 120 women with multilevel health promotion program and 125 women without multilevel health promotion program. The dependent variable was exclusive breastfeeding. The independent variable was multilevel health promotion program. The data were collected by questionnaire, indepth interview, and focus group discussion. Difference in percent of exclusive breastfeeding between the two groups was tested by chi square. Qualitative data were analyzed by content analysis.

Results: Percent of women who breastfed in the multilevel health promotion program was 2.4 times as many as that in the control group.

Conclusion: Multilevel health promotion program is effective to enhance exclusive breastfeeding practice among lactating women.
\end{abstract}

Keywords: exclusive breastfeeding, evaluation, promotion program, multilevel

\section{Correspondence:}

Nur Khamidah. Department of Public Health, Faculty of Medicine, Universitas Wijaya Kusuma, Surabaya, Jl. Dukuh Kupang XXV/54 Surabaya, East Java.

Email: nurkhamidah2006@gmail.com. Mobile: 082227307087.

The 4th International Conference on Public Health

Best Western Premier Hotel, Solo, Indonesia, August 29-30, 2018 | 137 https://doi.org/10.26911/theicph.2018.02.18 